Hydraulic Engineering Repository

Ein Service der Bundesanstalt für Wasserbau

Emami, Soleyman; Schleiss, Anton

Prediction Of Localized Scour Hole On Natural Mobile Bed At

Culvert Outlets

Verfügbar unter / Available at:

https://hdl.handle.net/20.500.11970/100212

Vorgeschlagene Zitierweise / Suggested citation:

Emami, Soleyman; Schleiss, Anton (2010): Prediction Of Localized Scour Hole On Natural Mobile Bed At Culvert Outlets. In: Burns, Susan E.; Bhatia, Shobha K.; Avila, Catherine M. C.; Hunt, Beatrice E. (Hg.): Proceedings 5th International Conference on Scour and Erosion (ICSE-5), November 7-10, 2010, San Francisco, USA. Reston, Va.: American Society of Civil Engineers. S. 844-853. 


\title{
Prediction Of Localized Scour Hole On Natural Mobile Bed At Culvert Outlets
}

\author{
Soleyman Emami ${ }^{1}$ and Anton J. Schleiss ${ }^{2}$
}

${ }^{1}$ Mahab Ghodss consulting engineering, Tehran - Iran;

Email: Soleyman_emami@yahoo.com

${ }^{2}$ Laboratory of $\overline{\mathrm{Hy}}$ draulic Constructions (LCH), Swiss Federal Institute of Technology

of Lausanne (EPFL); Anton.Schleiss@epfl.ch

\begin{abstract}
Systematic physical tests were conducted to evaluate the natural mobile bed erosion without any protection measure. The experiments were performed using a hydraulic model built at the Laboratory of Hydraulic Constructions of the Swiss Federal Institute of Technology in Lausanne.In the preliminary tests, the principal parameters were found to be the discharge, tailwater depth, pipe diameter, and the bed material properties.

Upon the completion of scour tests, an empirical analysis was conducted to correlate the maximum depth, length, width and distance of maximum depth from the outlet, tailwater depth and downstream bed characteristics. The maximum depth, length and width of the scour hole were presented in dimensionless relationships for various of discharges and tailwater depths. Based on the tests results, general applicable design charts and formulas for defining the local scour hole have been developed. The results of present experimental study have compared with some results of other authors.
\end{abstract}

\section{Experimental work}

\subsection{Experimental facility}

The experiments were conducted using a hydraulic model with $7 \mathrm{~m}$ length, $2.5 \mathrm{~m}$ wide and consist of different parts:

- A horizontal pipe with $10 \mathrm{~cm}$ diameter and $1.0 \mathrm{~m}$ length, which was connected to the pump. Water flow was controlled upstream of the pipe using a hand operated valve.

- Alluvial bed with $3.2 \mathrm{~m}$ length, $2.2 \mathrm{~m}$ width and $3 \%$ slope. The height of the bed was $0.7 \mathrm{~m}$ at the pipe outlet.

- Hand operated tailwater flip gate situated at $3.2 \mathrm{~m}$ from the pipe outlet to control the tailwater level.

- Basin with dimension of $1.2 \mathrm{~m}$ length and $1.5 \mathrm{~m}$ width at the end of the model which was equipped with a rectangular sharp-crest weir to measure the discharge.

- Outlet channel.

In all tests an almost uniform graded non-cohesive sediment $\sigma_{\mathrm{g}}=\sqrt{\left(\mathrm{d}_{84} / \mathrm{d}_{16}\right)}=3.16$ were used in the downstream area of the pipe At the beginning of each test, the sediment bed was levelled using guide rails on the side of the channel with a longitudinal slope of $3 \%$ (Figure 1, left). A hand operated tailwater flip gate was used downstream of the sediment bed to change the tailwater depth and a point gage for measuring the tailwater depth which was situated upstream of the gate (Figure 1, right). 

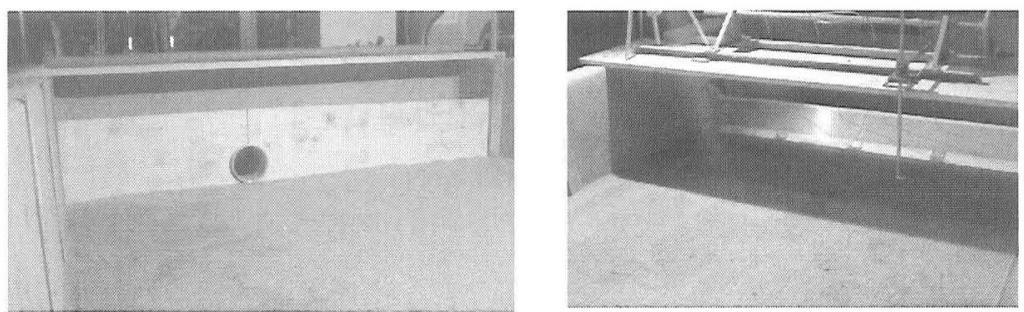

Figure 1: Alluvial bed; view towards upstream (left), view towards downstream, tailwater flip gate and point gage (right)

\subsection{Scope of tests}

In the preliminary tests, the principal parameters were found to be the discharge rate, the tailwater depth, the diameter of the pipe, and the bed material properties. The systematic tests investigated the effect of these principal parameters on the scour hole characteristics. Test conditions of these experimental studies are summarized in Table 1.

Table 1: Experimental conditions

\begin{tabular}{|c|c|}
\hline Tests & Natural bed \\
\hline Discharge $(1 / \mathrm{s})$ & $5.0<\mathrm{Q}<12.5$ \\
\hline $\begin{array}{c}\text { Tailwater variable } \\
(\mathrm{D}=10 \mathrm{~cm})\end{array}$ & $\begin{array}{c}0.1<\mathrm{h}_{\mathrm{TW}} / \mathrm{D}<0.2 \\
1.0<\mathrm{h}_{\mathrm{TW}} / \mathrm{D}<1.1\end{array}$ \\
\hline Discharge Intensity & $0.9<\mathrm{Q} /\left(\mathrm{g}^{0.5} \cdot \mathrm{D}^{2.5}\right)<1.3$ \\
\hline Densimetric Froude number & $7.5<\mathrm{F}_{0}<14.5$ \\
\hline $\begin{array}{c}\text { Geometric standard deviation of the bed, } \\
\sigma_{\mathrm{g}}=\sqrt{\left(\mathrm{d}_{84} / \mathrm{d}_{16}\right)}\end{array}$ & 3.16 \\
\hline $\mathrm{d}_{50} / \mathrm{D}$ & 0.008 \\
\hline
\end{tabular}

\subsection{Experimental procedure}

To start each test, flow was introduced slowly to avoid initial local scouring of the bed. When the tailwater depth was reached to the desired level, the flow rate was increased to desired discharge and then remained constant throughout the test period. The water surface was read with a point gage situated upstream of the tailgate and discharge was measured using a rectangular sharp-crest weir in the downstream basin of the hydraulic model. Each tests was allowed to continue for 2.5 hours in order to achieve almost equilibrium conditions. The rate of change of the scour profile between 75 minutes and 150 minutes was less than a few millimetres.

\section{Analysis of the results}

The results of tests in natural mobile bed were analysed in order to compare the local scour development in different conditions. The scour hole geometry for each series of tests was presented in dimensionless form and discussed. 
Upon the completion of 40 scour tests, an empirical analysis was conducted to correlate the maximum depth $\left(\mathrm{d}_{\mathrm{sc}}\right)$, length (L), width (W) and distance of maximum depth from the pipe outlet $(\mathrm{X})$ to the discharge, tailwater depth and downstream bed characteristics. Analysis of the results was performed using high and low tailwater depths.

\subsection{Dimensional analysis}

Scour hole geometry depends on many variables that characterize the conduit, the bed material and the flow. These parameters are:

- velocity $u_{0}$

- tailwater depth, $h_{T W}$

- pipe diameter, $D$

- pipe slope, $S$

- pipe roughness coefficient, $n$

- particle size of the bed material, $d_{50}$

- density of the bed material, $\rho_{S}$

- water density, $\rho$

- dynamic viscosity of the water, $\mu$

- acceleration due to gravity, $g$

Thus, if " $y$ " represents any dimension of the scour hole, then

$\mathrm{y}=\mathrm{f}\left(\mathrm{u}_{0}, \mathrm{~h}_{\mathrm{TW}}, \mathrm{D}, \mathrm{S}, \mathrm{n}, \mathrm{d}_{50}, \rho_{\mathrm{s}}, \rho, \mu, \mathrm{g}\right)$

However, for the purpose of this study some of these variables can be disregarded, and only the more significant ones are preserved. First, $\mathrm{S}=0$ since the pipe was horizontal. Furthermore the water viscosity $\mu$ was assumed to be constant. The pipe roughness coefficient $\mathrm{n}$ was also eliminated, because the same pipe was used during all the tests. Thus the equation (1) simplifies to:

$\mathrm{y}=\mathrm{f}\left(\mathrm{u}_{0}, \mathrm{~h}_{\mathrm{TW}}, \mathrm{D}, \mathrm{d}_{50}, \rho_{\mathrm{s}}, \rho, \mathrm{g}\right)$

Upon performing dimensional analysis, the following non-dimensional function was obtained:

$\mathrm{y}=\mathrm{f}\left(\mathrm{F}_{0}, \mathrm{~h}_{\mathrm{TW}} / \mathrm{D}\right)$

In the equation (5.3), $F_{0}$ represents the densimetric Froude number expressed as $u_{0} / \sqrt{\left(\rho_{s} / \rho-1\right) \cdot g \cdot d_{50}}$.

\subsection{Definition of the scour hole geometry}

The different parameters of the scour hole geometry are described in Figure 2.

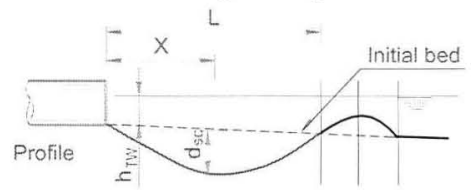

Figure 2: Definition sketch for scour hole geometry 


\subsection{Tailwater effect}

The results of the scour hole for high and low tailwater depths are shown in Figure 3.
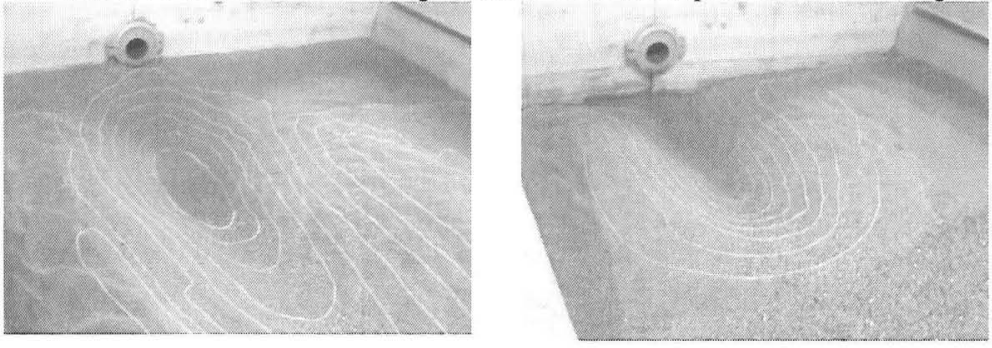

Figure 3: high tailwater depth (left), low tailwater (right) $-Q=12.5 \mathrm{l} / \mathrm{s}$

\subsection{Equilibrium scour profile}

Figure 4 represents the equilibrium scour profiles during experimental tests under a variety of discharge and tailwater conditions.
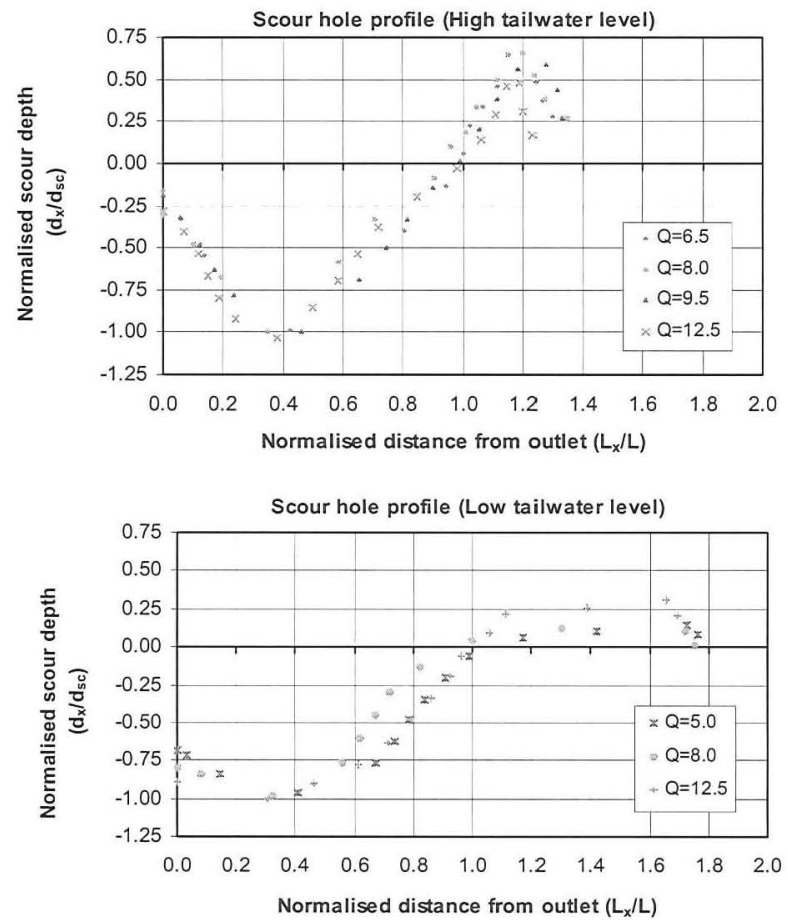

Figure 4: Equilibrium scour profile with different discharges and tailwater conditions 
According to the equilibrium scour profile, it is observed that:

- The maximum erosion depth is located about $40 \%$ of the maximum scour length from the pipe outlet in case of high tailwater depth $\left(1.0<\mathrm{h}_{\mathrm{TW}} / \mathrm{D}<1.1\right)$,

- For low tailwater depth $\left(0.1<\mathrm{h}_{\mathrm{TW}} / \mathrm{D}<0.2\right)$, the maximum erosion depth is located about $30 \%$ of the maximum scour length from the pipe outlet,

- Scour depth at the pipe outlet for high and low tailwater depth is $25 \%$ and $75 \%$ of the maximum scour depth respectively.

\subsection{Graphical representation of the experimental data}

According to the dimensional analysis, the parameters of the scour hole geometry were correlated to the densimetric Froude number, $\mathrm{F}_{0}$, as:

$F_{0}=u_{0} / \sqrt{\left(\rho_{s} / \rho-1\right) \cdot g \cdot d_{50}}$

Logarithmic regression lines were compiled correlating the scour hole depth for different tailwater conditions to the densimetric Froude number as presented in Figure 5. This type of line had the highest Correlation coefficient, $r^{2}$, comparing than the other types.

Similar plots were compiled for the scour length, the distance of maximum scour depth from the pipe outlet and the scour width. These results are presented in Figures $6-7$ respectively.

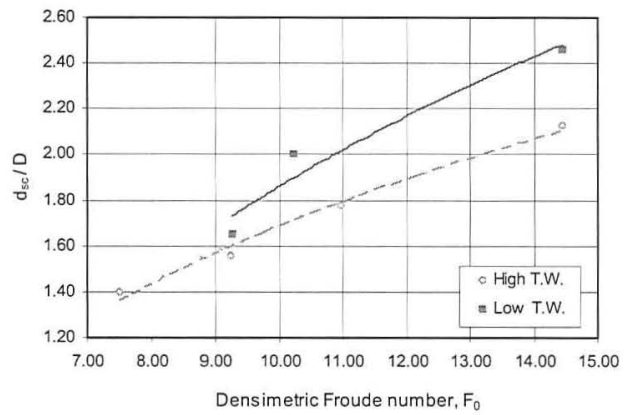

Figure 5: Variation of the scour hole depth with the densimetric Froude number

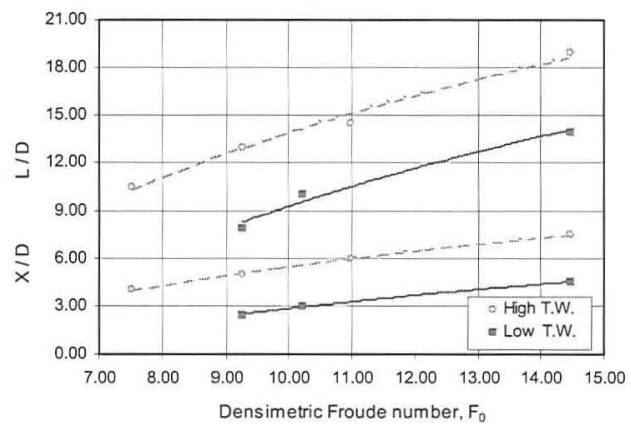

Figure 6: Variation of the scour hole length and the distance of maximum scour depth from pipe outlet with densimetric Froude number 


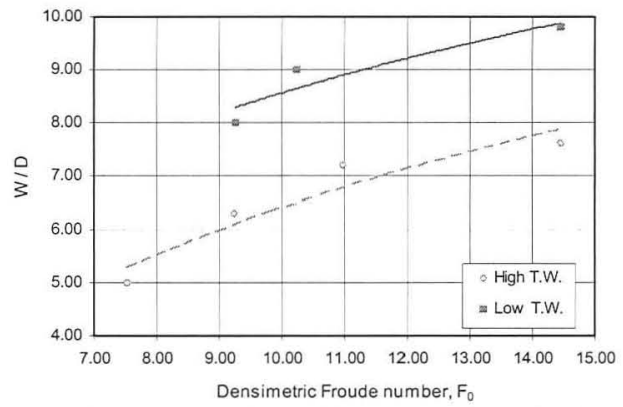

Figure 7: Variation of the scour width with the densimetric Froude number

Graphical representation of data indicates that for $7.5<\mathrm{F}_{0}<14.5$ :

- For similar values of the densimetric Froude number, the maximum depth of scour hole; $d_{\mathrm{sc}}$, is approximately $10-25 \%$ more in case of low tailwater depth.

- The value of $L / D$ and X/D are less than the corresponding value for the case with high tailwater depth.

- The scour hole width; W, is approximately $30 \%$ more in case of low tailwater depth.

\subsection{Formula for evaluation of the scour hole on mobile riverbed}

According to the analysis of the experimental data, the non-dimensional relationships of scour hole geometry for each tailwater depth can be written as:

$\mathrm{d}_{\mathrm{sc}} / \mathrm{D}, \mathrm{L} / \mathrm{D}, \mathrm{X} / \mathrm{D}$ and $\mathrm{W} / \mathrm{D}=\mathrm{f}\left(\mathrm{F}_{0}\right)$

In order to find the highest Correlation coefficient, $r^{2}$, different regression lines were fitted through the data. The best result was a logarithmic regression as an equation with the form of $y=a \cdot \ln (x)+b$

where;

$\mathrm{y}=$ dimensionless parameter of the scour hole, $\mathrm{a}, \mathrm{b}=$ constant

$x=$ the densimetric Froude number defined $u_{0} / \sqrt{\left(\rho_{s} / \rho-1\right) \cdot g \cdot d_{50}}$

The parameters and coefficients of the equation (4) summarized in Table 2.

Table 2: Summary of equation coefficients

\begin{tabular}{|l|c|c|c|c|c|}
\hline Scour hole characteristics & $\mathrm{y}$ & $\mathrm{a}$ & $\mathrm{b}$ & $\begin{array}{c}\text { Tailwater } \\
\text { condition }\end{array}$ & $\begin{array}{c}\text { Correlation } \\
\text { coefficient, } \mathrm{r}^{2}\end{array}$ \\
\hline Maximum scour depth & \multirow{2}{*}{$\mathrm{d}_{\mathrm{sc}} / \mathrm{D}$} & $\begin{array}{c}1.14 \\
1.69\end{array}$ & $\begin{array}{c}-0.93 \\
-2.04\end{array}$ & $\begin{array}{c}1.05 \cdot \mathrm{D} \\
0.15 \cdot \mathrm{D}\end{array}$ & $\begin{array}{l}0.99 \\
0.95\end{array}$ \\
\hline \multirow{2}{*}{ Maximum scour length } & $\mathrm{L} / \mathrm{D}$ & 12.81 & -15.55 & $\begin{array}{c}1.05 \cdot \mathrm{D} \\
0.15 \cdot \mathrm{D}\end{array}$ & 0.99 \\
& & 13.15 & -21.02 & 0.98 \\
\hline Distance of $\mathrm{d}_{\mathrm{sc}}$ from pipe & \multirow{2}{*}{$\mathrm{X} / \mathrm{D}$} & 5.39 & -6.92 & $1.05 \cdot \mathrm{D}$ & 0.99 \\
outlet & & 4.62 & -7.82 & $0.15 \cdot \mathrm{D}$ & 0.99 \\
\hline \multirow{2}{*}{ Maximum scour width } & $\mathrm{W} / \mathrm{D}$ & 3.97 & -2.72 & $1.05 \cdot \mathrm{D}$ & 0.91 \\
& & 3.59 & 0.28 & $0.15 \cdot \mathrm{D}$ & 0.87 \\
\hline
\end{tabular}


In Figure 8, the values of the coefficients " $a$ " and "b" are presented versus $h_{T W} / D$ for each dimensionless parameter of the scour hole.

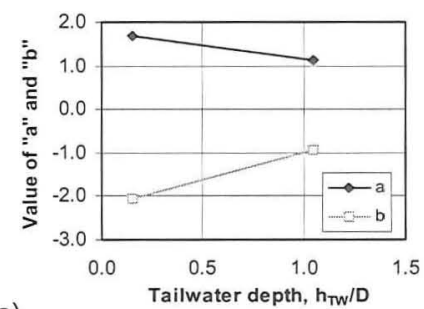

a)

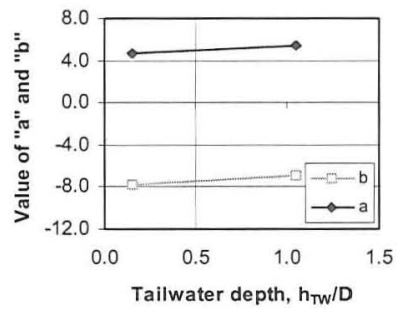

Figure 8: Values of the coefficients " $a$ " and " $b$ " versus tailwater depth for; a) maximum scour depth, b) maximum scour length, c) distance of maximum scour depth from the pipe outlet, d) maximum width of scour

The values of "a" and "b" with function of hTW/D are presented in Table 3. Scour hole characteristics could be calculated using these values in the equation $4, y=a \cdot \ln (x)+b$.

$x=u_{0} / \sqrt{\left(\rho_{s} / \rho-1\right) \cdot g \cdot d_{50}}$

Table 3: Summary of equation coefficients, scour hole on natural mobile bed function of tailwater depth

\begin{tabular}{|c|c|c|}
\hline $\begin{array}{c}\text { Dependent variable of } \\
\text { scour hole geometry, }\end{array}$ & $\mathrm{a}$ & $\mathrm{b}$ \\
\hline $\mathrm{d}_{\mathrm{sc}} / \mathrm{D}$ & $-0.60 \cdot\left(\frac{\mathrm{h}_{\text {TW }}}{\mathrm{D}}\right)+1.80$ & $1.23 \cdot\left(\frac{\mathrm{h}_{\text {TW }}}{\mathrm{D}}\right)-2.25$ \\
\hline $\mathrm{L} / \mathrm{D}$ & $-0.38 \cdot\left(\frac{\mathrm{h}_{\mathrm{TW}}}{\mathrm{D}}\right)+13.20$ & $6.08 \cdot\left(\frac{\mathrm{h}_{\mathrm{TW}}}{\mathrm{D}}\right)-21.95$ \\
\hline $\mathrm{X} / \mathrm{D}$ & $0.86 \cdot\left(\frac{\mathrm{h}_{\text {TW }}}{\mathrm{D}}\right)+4.49$ & $1.00 \cdot\left(\frac{\mathrm{h}_{\text {TW }}}{\mathrm{D}}\right)-7.97$ \\
\hline $\mathrm{W} / \mathrm{D}$ & $-0.42 \cdot\left(\frac{\mathrm{h}_{T W}}{\mathrm{D}}\right)+3.53$ & $-3.33 \cdot\left(\frac{\mathrm{h}_{\text {TW }}}{\mathrm{D}}\right)+0.78$ \\
\hline
\end{tabular}




\section{Comparison of the results}

Formulas proposed for calculating scour hole characteristics by different authors have been presented in Table 4. It is established that scour hole is calculable using tailwater depth, culvert outflow velocity and particle size of the bed material. In this chapter, the results of present experimental study for scour hole on natural mobile bed have compared with some other authors results.

\section{Table 4: Comparison of different formulas conditions}

\begin{tabular}{|c|c|c|c|c|c|}
\hline Researchers & $\begin{array}{l}\text { Vertical } \\
\text { dimensi } \\
\text { on of } \\
\text { the jet } \\
(\mathrm{mm})\end{array}$ & $\begin{array}{l}\text { Densimetric } \\
\text { Froude F0 }\end{array}$ & $\begin{array}{l}\text { Discharge } \\
\text { intensity }\end{array}$ & $\begin{array}{l}\text { Submer } \\
\text { ged } \\
\text { ratio } \\
\mathrm{hTW} / \mathrm{D}\end{array}$ & $\begin{array}{l}\text { Maximum scour depth } \\
\text { formulas }\end{array}$ \\
\hline $\begin{array}{l}\text { Present } \\
\text { study }\end{array}$ & 100 & $7.5-14.5$ & $0.9-1.3$ & $\begin{array}{l}0.15 \\
1.05\end{array}$ & $\begin{array}{c}\mathrm{dsc} / \mathrm{D}=\mathrm{a} \cdot \ln (\mathrm{x})+\mathrm{b} \\
\mathrm{a}=-0.60 \cdot\left(\frac{\mathrm{h}_{\mathrm{TW}}}{\mathrm{D}}\right)+1.80 \\
\mathrm{~b}=1.23 \cdot\left(\frac{\mathrm{h}_{\mathrm{TW}}}{\mathrm{D}}\right)-2.25 \\
\mathrm{x}=\mathrm{u}_{0} / \sqrt{\left(\rho_{\mathrm{s}} / \rho-1\right) \cdot \mathrm{g} \cdot \mathrm{d}_{50}}\end{array}$ \\
\hline $\operatorname{Lim}(1995)$ & 15,26 & $1.91-24.6$ & & 0.47 & $\mathrm{dsc} / \mathrm{D}=\left(\frac{3.68}{\sigma_{\mathrm{g}}^{0.4}}\right) \cdot \mathrm{F}_{0}^{0.57} \cdot\left(\frac{\mathrm{d}_{50}}{\mathrm{D}}\right)^{0.4}$ \\
\hline $\begin{array}{l}\text { Abt et al. } \\
(1987)\end{array}$ & 102 & $7.2-21.81$ & $\begin{array}{c}0.9-3.14 \\
\text { (circular) }\end{array}$ & $\begin{array}{c}0.45 \\
( \pm 0.05)\end{array}$ & $\begin{array}{c}d_{S d} / R_{H}= \\
7.84 \cdot\left(Q /\left(A \cdot g^{0.5} \cdot R_{H}^{0.5}\right)\right)^{0.28}\end{array}$ \\
\hline $\begin{array}{c}\text { Abt, } \\
\text { Kloberdanz, } \\
\text { Mendoza } \\
(1984) \\
\end{array}$ & $\begin{array}{l}102 \\
254\end{array}$ & $2.0-24.4$ & $0.3-3.1$ & 0.45 & $d_{s c} / D=1.77 \cdot\left(\frac{Q}{g^{0.5} \cdot D^{2.5}}\right)^{0.63}$ \\
\hline $\begin{array}{c}\text { Abt, Ruff, } \\
\text { Mendoza } \\
(1983)\end{array}$ & 102 & & $0.4-3.0$ & 0.45 & $d_{s c} / D=2.08 \cdot\left(\frac{Q}{g^{0.5} \cdot D^{2.5}}\right)^{0.37}$ \\
\hline $\begin{array}{l}\text { Ruff et al. } \\
\quad(1982)\end{array}$ & $\begin{array}{c}100.7 \\
260 \\
345 \\
446\end{array}$ & $7.3-33.7$ & & $\begin{array}{l}0.00 \\
0.25 \\
0.45\end{array}$ & $\mathrm{~d}_{\mathrm{sc}} / \mathrm{D}=2.07 \cdot\left(\frac{\mathrm{Q}}{\mathrm{g}^{0.5} \cdot \mathrm{D}^{2.5}}\right)^{0.45}$ \\
\hline $\begin{array}{c}\text { Abt and } \\
\text { Ruff (1982) }\end{array}$ & $\begin{array}{l}273 \\
356 \\
457\end{array}$ & & $0.5-2.0$ & $\begin{array}{c}0.45 \\
( \pm 0.05)\end{array}$ & $d_{s d} / D=0.86 \cdot\left(\frac{\rho \cdot u_{0}^{2}}{\tau_{c}}\right)^{0.18}$ \\
\hline
\end{tabular}

Graphical comparison of the present experimental results and six other scour formulas are shown in Figure 9. The tests conditions of these six formulas indicate that all have concentrated on flow depth downstream of culverts less than half of the diameter, $h_{T w} / D$ $=0.45$.

In order to investigate the variation of the scour hole due to tailwater depth, the results of scouring for two other tailwater depths below and over the mentioned ratio have been presented by the present study.

The "hidden line" represents the mean values of the six scour formulas results and two other lines below and over show the present experimental results for submergence ratio of $1.05 \mathrm{D}$ and $0.15 \mathrm{D}$ respectively. 

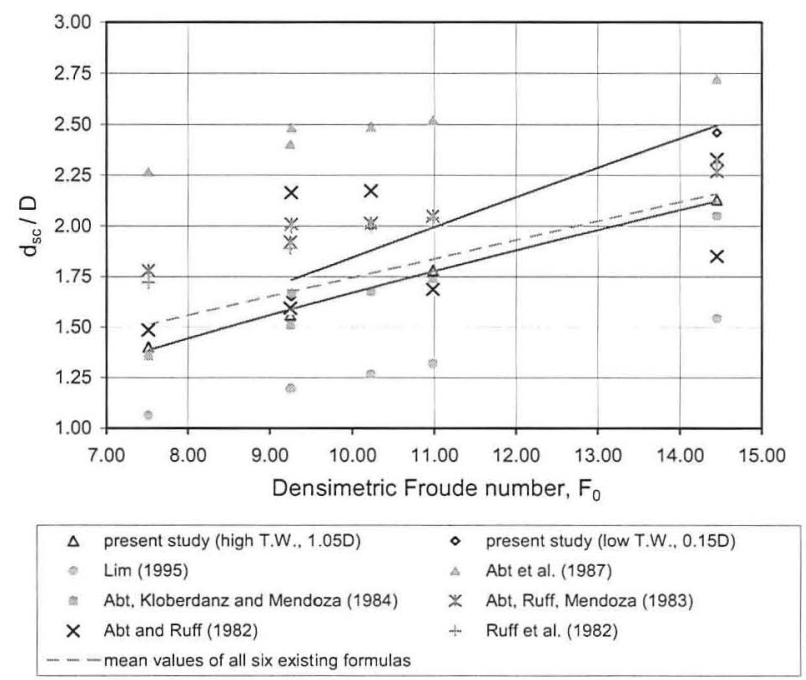

Figure 9: Comparison of the maximum scour depth results between the present study and other authors

On the six selected equations, only three equations defined the length and width of the scour hole. They consist of Abt et al. (1987), Abt, Kloberdanz, Mendoza (1984), and Abt and Ruff (1982).

It should be noted that the results of Abt et al. (1987) for the length of the scour hole has been eliminated because the scour length from square culverts deviated as much as $40 \%$ from the scour length of the circular culverts.

\section{Conclusions}

The experimental study for non-cohesive bed material led to the following conclusions:

- For low and high tailwater depths, the maximum erosion depth was located about $30 \%$ and $40 \%$ of the maximum scour length from the pipe outlet respectively.

- Scour depth immediately at the pipe outlet was $25 \%$ and $75 \%$ of the maximum scour depth for high and low tailwater depths respectively.

- For similar values of the densimetric Froude number, the maximum depth of scour hole was approximately $10-25 \%$ deeper in case of low tailwater depth.

- The scour hole length increased and the scour hole width decreased while increasing the tailwater level.

- The mean values of all investigated existing formulas were found to be close to the present study. The closer results were identified by the formulas of Abt, Kloberdanz \& Mendoza (1984) and Abt \& Ruff (1982), which had almost similar test conditions as the present study.

- Results of Lim (1995) and Abt et al. (1987) were found below and above the other experimental results. Lim (1995) used rather small culvert diameters and Abt et al. (1987) used different culvert shapes. 


\section{REFERENCES}

Abida, H. \& Townsend, R.D. (1991). Local scour downstream of box-culverts. Journal of Irrigation and Drainage Engineering. Vol. 117, No. 1. pp. 425 - 440.

Abt, S.R. \& Ruff, F. (1982). Estimating culvert scour in cohesive material. Journal of Hydraulic Division, Proceeding of the American Society of Civil Engineering, ASCE, Vol. 108, No. 1. pp. $25-34$.

Abt, S.R., Kloberdanz, R.L. \& Mendoza, C. (1984). Unified culvert scour determination. Journal of Hydraulic Engineering, Vol. 110, No. 10. pp. 475 - 479.

Abt, S.R., Ruff, J.F., Doehring, F.K. \& Donnell, C.A. (1987). Influence of culvert shape on outlet scour. Journal of Hydraulic Engineering, ASCE, Vol. 113. pp. 475 - 479.

Bohan, J.P. (1970). Erosion and riprap requirements at culvert and storm-drain outlets. US Army Engineers Waterways Experiment Station, Vicksburg, Mississippi, Report No. H-70-2.

Breusers, H.N.C. \& Raudkivi, A.J. (1991). Scouring. IAHR, Hydraulic Structures Design Manual. No. 2.

Chiew, Y. \& Lim, S.Y. (1996). Local scour by a deeply submerged horizontal circular jet. Journal of Hydraulic Engineering, Vol. 122, No. 9. pp. $529-532$.

Day, R.A., Liriano, S.L. \& White, W.R. (2001). Effect of tailwater depth and model scale on scour at culvert outlet. Proceedings of the Institution of Civil Engineering, Water \& Maritime Engineering 148.

Hoffmans, G.J.C.M. \& Verheij, H.J. (1997). Scour Manual. Balkema: Rotterdam.

Mendoza, C. (1980). Headwall influence on scour at culvert outlets. Thesis presented to Colorado State University, at Fort Collin, Colo.

Mendoza, C., Abt, S.R. \& Ruff, F. (1983). Headwall influence on scour at culvert outlets. Journal of Hydraulic Engineering, Vol. 109, No. 7.

pp. $1056-1060$.

Oliveto, G. \& Hager, W.H. (2002). Temporal evolution of clear-water pier and abutment scour. Journal of Hydraulic Engineering, Vol. 128, No. 9. pp. $811-820$.

Opie, T.R. (1967). Scour at culvert outlets. MSc Thesis, Colorado State University, Fort Collin, Colorado.

Rajaratnum, N. \& Berry, B. (1977). Erosion by circular turbulent wall jets. Journal of Hydraulic Research. IAHR. No. 3, pp. $277-289$.

Rajaratnum, N. \& Diebel, M. (1981). Erosion Below Culvert-like Structures, Sixth Canadian Hydrotechnical Conference, pp. $469-484$.

Rajaratnam, N. (1998). Generalized study of erosion by circular horizontal turbulent jets. Journal of Hydraulic Research, Vol. 36, No.4. pp. $613-635$.

Stevens, M. A., and Simons, D. B. (1971). Stability analysis for course granular material on slopes. River Mechanics, H. W. Shen, Ed., Fort Collins, Colorado, 1, 17 - 1 Straub, L.G. Dredge fill closure of Missouri River at Fort Randall. Proceeding of Minnesota International Hydraulics Convention, Minneapolis, Minnesota. pp $61-75$.

Valentin, F. (1967). Consideration concerning scour in case of flow under gates. Proceeding, 12th Congress, IAHR, Vol. 3, Colorado State University, Fort Collins, Colorado.

Whittaker, J.G. \& Schleiss, A. (1984). Scour related to energy dissipaters for high head structures. ETHZ - VAW Report No. 73, Zürich. 